\title{
The relationship between anomia and maladaptive personality traits
}

\author{
J. Levina*, V. Perejolkina, K. Martinsone, S. Mihailova, and J. Kolesnikova \\ Rīga Stradiņš University, Riga, Latvia
}

\begin{abstract}
Research of anomia is topical in the period when a society endures social and economic changes. On the other hand, the modern Western society is characterized by a rapid speed of development, by diversity, variability, multicultural life. In such conditions for some individuals it could be difficult to make life choices. Such individuals can get into "an anomic state". In a situation of rapid social and political changes as well as simply in the modern diverse and rapidly developing society pathological personality traits can serve as a factor that aggravates anomic feelings. Thus, the main purpose of this research is to investigate relations between anomia and pathological personality traits. The sample consisted of 83 Latvian inhabitants aged from 19 to 47 years (16.9\% males, 83.1\% females). The Anomia Questionnaire - AQ [1] and the Latvian Clinical Personality Inventory - LCPI v2.2 [2] were used. It is found that there are multiple relations between all six sub-dimensions of anomia and certain different maladaptive personality traits. Irresponsibility is the only personality trait that predicts deviation from prescribed rules or customs. Negative emotionality is the only significant predictor for social distrust. Suspiciousness that falls within a first-order domain Psychoticism and a second-order domain Schizotypy is the most significant predictor of estrangement to others as a dimension of anomia. Eccentricity that falls within a first-order domain Psychoticism and a second-order domain Schizotypy is the most significant predictor of cultural isolation. Separation insecurity that falls within a first-order domain Dependence and a second-order domain Neuroticism is the most significant predictor of a lack of goal clarity as a dimension of anomia. Depression as a pathological personality trait that falls within a first-order domain Negative emotionality and a second-order domain Neuroticism is the most significant predictor of a lack of goal clarity as a dimension of anomia.
\end{abstract}

\section{Introduction}

Research of anomia is topical in the period when a society endures social and economic changes. It is acknowledged that social, economic, political, cultural changes at the level of a society cause anomie - the condition or state, in which there is a breakdown of social norms and guidance for the citizens of a society [3] as well the discrepancy between common social goals and the legitimate means to attain those goals [4]. In its turn, at the

\footnotetext{
* Corresponding author: jelena. levina@rsu. Iv
} 
individual level such changes can cause anomia - "subjectively perceived anomie". While anomie refers to the state of a society characterized by the lack of norms and regulations, anomia characterizes the level of the individual state [5].

During the last decades both worldwide and in Latvia, rapid social and economic changes took place, such as the economic crisis, changes in the labour market, labour migration and others. All these transitions in the development of our society, social and economic changes could affect individuals and cause anomia.

On the other hand, the modern Western society is characterized by a rapid speed of development, by diversity, variability, multicultural life. In such conditions for some individuals it could be difficult to make life choices, to choose unambiguous and accurate norms and guidance for their behaviour. Such individuals can get into "an anomic state", namely, they could develop a deviant behaviour, lose social trust, feel social isolation, feel difficulties when it is necessary to choose life goals, feel a sense of generalized meaninglessness.

There is an empirical evidence of negative influences of anomia. It was found that anomia is negatively associated with subjective well-being - overall life satisfaction, satisfaction with separate life domains, and general sense of happiness [6, 7]. Anomia is negatively related with such significant values as politics and religion [8]. In a recent brief review of publications on anomia [9] it was shown that (1) anomic feelings are connected with higher suicidal tendencies [10,11]; (2) anomia is associated with substance use [12]; (3) anomic individuals have low self-esteem [13]. Therefore, an important task is to investigate factors affecting anomia.

Pathological personality traits are recognized as one of important determinants of pathology and unsuccessful human functioning. For example, there is empirical evidence that pathological personality traits are associated with internalizing psychopathology [14], the aversive interpersonal behaviours [15], intimate partner violence [16], pathological gambling [17], the aggressive and self-defeating humour styles [18].

In a situation of rapid social and political changes as well as simply in the modern diverse and rapidly developing society pathological personality traits can serve as a factor that aggravates anomic feelings. Thus, the main purpose of this research is to investigate relations between anomia and pathological personality traits.

\section{The concept and the integrative multidimensional model of anomia}

The integrative multidimensional model of anomia was developed by Luevina, Mārtinsone and co-authors [19-23]. According to this model anomia is defined as an individual psychological state when a person believes that there are no social norms, rules and prescriptions, which can regulate his/her own behaviour as well as the behaviour of other citizens of a society, when a person endures the psychological state of social isolation and meaninglessness.

According to this model, anomia is a multidimensional construct and includes three main dimensions: Normlessness, Social isolation, and Meaninglessness. Normlessness is defined as a perceived breakdown of a social order in which norms no longer regulate behaviour. Social isolation is defined as a loss of a sense of community. At last, meaninglessness is defined as an absence or unclearness of terminal goals (life meanings) as prescriptions for an individual's behaviour.

Each major dimension of anomia is divided into two sub-dimensions:

$>$ Normlessness includes an individual's deviation from prescribed rules or customs and social distrust;

Social isolation includes estrangement to others and cultural isolation. 
Meaninglessness includes lack of goal clarity and generalized sense of meaninglessness.

\section{Factors influencing anomia}

Theorists of anomia [3, 24, 25] consider that both negative and positive social and economic changes, e.g. socially economic blossoming and crises, can cause anomie at the level of society and anomia at the level of an individual, however, more often exactly periods of sharp crises lead to this state.

From a psychological point of view, it is important to investigate which individual factors affect anomia. Up to now some studies were conducted in which such factors as socially demographic characteristics, namely, sex and age, and participation in social activities, including voluntary work were investigated [7, 9, 22].

Regarding socially demographic characteristics it was found that there was a significant difference in multidimensional anomia between different age groups. Middle-aged adults had higher scores for social isolation than respondents from the group of early adults. Late adolescents-youths had the lowest scores for meaninglessness comparing with all other age groups. Early adults had lower scores for meaninglessness than middle and late adults. Sex differences were no found [22].

Regarding participation in social activities it was found that such aspects of anomia as social distrust, social isolation and meaninglessness were negatively associated with social activities - interacting with others without doing a specific activity with them, doing an activity with others, helping others and contributing to society or civic activities [9].

While a great significance of maladaptive personality traits for health and psychosocial functioning is obvious, there were no studies in which relations between anomia and pathologic personality traits were explored.

\section{Multidimensional models of pathologic personality traits}

The DSM-5 Personality and Personality Disorders Work Group proposed a substantial shift to a dimensional conceptualization and diagnosis of personality pathology [26]. In the alternative DSM-5 model for personality disorders (PDs), PDs are characterized by impairments in personality functioning and particular constellations of pathologic personality traits. The recognition of the many limitations of the categorical model of personality disorder classification led to the development of quit a number of alternative proposals for a dimensional classification of personality disorders [27]. During past decades, different models of pathologic or maladaptive personality traits have been developed [27] and most of them more or less represent maladaptive variants of the five domains of the extensively validated and replicated personality model known as the "Big Five", or Five Factor Model of personality (FFM).

One of such models of pathologic personality traits was developed in Latvia as a theoretical frame for Latvian Clinical Personality Inventory (LCPI-v3) [2]. First, based on a theoretical analysis of existing models of pathologic personality traits, a list of 40 traits - a combination of traits listed in Samuel et al. [26], Wright et al. [28], DSM-5 Section III (PSY-5 model, APA, [29]) was prepared and used in deductively derived preliminary versions of 40 pathologic personality trait scales [30], and then, based on the results of a factor analytic study [31] a final model of 33 facet-level pathological personality traits that comprise seven first-order domains (namely, Psychoticism, Introversion, Narcissism, Impulsivity, Dependence, Negative emotionalism and Compulsivity), which in their turn, 
can be grouped in four second-order domains (Schizotypy, Antagonism, Neuroticism and Compulsivity) was developed.

According to this multidimensional hierarchical model six facet-level pathological personality traits - cognitive non-regulation, dissociation proneness, eccentricity, suspiciousness, unusual beliefs, and self-harm - fall within a higher-order domain Psychoticism. Three pathological personality traits - restricted affectivity, social withdrawal, close relationship avoidance - fall within a higher-order domain Introversion. In their turn, Psychoticism and Introversion form a second-order domain Schizotypy.

Four facet-level pathological personality traits - aggression, irresponsibility, rashness, risk taking - fall within a higher-order domain Impulsivity. Six pathological personality traits - dominance, arrogance, attention seeking, manipulative behaviour, harshness, and deceitfulness - fall within a higher-order domain Narcissism. Impulsivity and Narcissism form a second-order domain Antagonism.

Seven facet-level pathological personality traits - intemperance, emotional stability, emotional instability, depressiveness, anxiousness, impersistence, and distrustfulness - fall within a higher-order domain Negative emotionality. Four facet-level pathological personality traits - evaluation apprehension, submissiveness, indecisiveness, and separation insecurity - fall within a higher-order domain Dependence. Negative emotionality and Dependence form a second-order domain Neuroticism.

Finally, three facet-level pathological personality traits - pedantry, perseveration, and perfectionism - fall within a higher-order domain Compulsivity. This domain remains as a second-order factor Compulsivity.

\section{The present study}

Examination of the existing literature allows concluding that social, economic, political, cultural changes as well as overall such characteristic of modern society as a high speed of development and diversity cause anomia at the individual level. Anomia is a multidimensional construct and could be experienced as an individual's deviation from prescribed rules or customs, social distrust, estrangement to others, cultural isolation, a lack of goal clarity and generalized sense of meaninglessness.

In the current study we hypothesized that maladaptive personality traits (a tendency to feel, perceive, behave, and think in relatively consistent ways across time and across situations in which the trait may manifest (APA, [29]) can be factors that mediate the relations between a situation of rapid changes and transitions and anomia. Thus, the purpose of this research is to determine whether there are the relations between anomia and maladaptive personality traits.

We formulate the following research questions:

1) What are the relations between dimensions of anomia and pathological personality domains and facet-level traits?

2) What pathological personality domains and traits best predict specific dimensions of anomia?

\section{Methods}

\subsection{Participants}

The sample consisted of 83 respondents, aged from 19 to 47 years $(M=24.29, S D=6.65)$, $16.9 \%$ were males and $83.1 \%$ were females. Majority (67.5\%) of respondents live in Riga, $13.3 \%$ of respondents live in another large city in Latvia. The rest respondents live in a 
small town or in a rural settlement; $84.3 \%$ are Latvians, $12.0 \%$ are Russians, the rest part of respondents $(2.4 \%)$ have another nationality or simply did not indicate it.

Regarding family status, $18.1 \%$ indicated that they are married, $26.5 \%$ live together with a boyfriend/girlfriend, but are not officially married, $1.2 \%$ is divorced, and $53.0 \%$ never had registered official marriage or lived with a partner unofficially. Other respondents did not indicate their family status.

Regarding education level, $18.1 \%$ of respondents have secondary education, $4.8 \%$ of respondents have special secondary education or vocational secondary education, the largest part (51.8\%) of respondents have unfinished higher education, $4.8 \%$ of respondents have a higher education (I level) and 14.5\% have a higher education (II level, Bachelor's degree), $6 \%$ of respondents have a Master's degree.

Income level distribution in the sample was as follows: $4.8 \%$ of respondents have level of income that is completely satisfying and $57.8 \%$ have level of income that was subjectively characterised as satisfying, $33.7 \%$ of respondents are unsatisfied with their level of income. The rest respondents did not specify their level of income.

\subsection{Instruments}

\subsubsection{Anomia Questionnaire (AQ)}

The Anomia Questionnaire - AQ [1] was used. The questionnaire includes 24 statements. Responses are made on a 5-point Likert scale (from 1 - strongly disagree till 5 - strongly agree). The questionnaire is in Latvian.

The questionnaire consists of six scales (Deviation from prescribed rules or customs, Social distrust, Estrangement to others, Cultural isolation, Lack of goal clarity, Generalized sense of meaninglessness) and, respectively, measures six sub-dimensions of anomia. All the AQ scales have high internal consistency - Cronbach's alpha vary from .73 to .86 (L̦evina, Mārtinsone, in press).

\subsubsection{Latvian Clinical Personality Inventory (LCPI v2.2)}

Participants filled in the second preliminary item pool of the Latvian Clinical Personality Inventory (LCPI v2.2, $k=664$ ) [32], but for scale scoring the final version of this inventory (LCPI-v3; [2]) was used. Responses were made on a 4-point Likert scale (from 0 - strongly disagree till 3 - strongly agree).

The questionnaire is in Latvian. The LCPI-v3 includes 322 statements which could be scored in nine clinical scales, five functional scales, five additional scales and 33 facet-level pathological personality trait scales that form seven first-order domain-level scales and four second-order personality domain-level scales. Clinical scales of LCPI-v3 are: Depression symptoms scale (DP), Symptoms of posttraumatic stress disorder (PTSD), General anxiety symptoms (GA), Panic attack symptoms (PA), Symptoms of social anxiety (SA), Alcohol related problems (ALCO), Drug related problems (DRUG), Somatic symptoms (SM) and Psychotic symptoms (PSS); five functioning scales of LCPI-v3 are: Sleep problems (F1), Energy level (F2), Psychomotor retardation and diminished cognitive function (F3), Problems associated with attention functions (F4), and Communication problems (F5); Additional scales of LCPI-v3 are: Suicide ideation (SI), Low self-esteem (LSE), Stress symptoms (STRS) Perceived social support (PSS) and Unstable and intense interpersonal relationships (REL).

In this research only these 33 facet-level, seven first-order and four second-order domain-level scales of pathological personality traits were used. Used facet-level scales are 
as follows: Cognitive non-regulation, Dissociation proneness, Eccentricity, Suspiciousness, Unusual beliefs, Self-harm, Restricted affectivity, Social withdrawal, Close relationship avoidance, Aggression, Irresponsibility, Rashness, Risk taking, Dominance, Arrogance, Attention seeking, Manipulative behaviour, Harshness, Deceitfulness, Intemperance, Emotional stability, Emotional instability, Depressiveness, Anxiousness, Impersistence, Distrustfulness, Evaluation apprehension, Submissiveness, Indecisiveness, Separation insecurity, Pedantry, Perseveration, and Perfectionism. Seven personality domain-level scales (first-order factors) are as follows: Psychoticism, Introversion, Impulsivity, Narcissism, Negative emotionality, Dependence, Compulsivity. Finally, four major personality domain-level scales (second-order factors) are as follows: Schizotypy, Antagonism, Neuroticism, and Compulsivity. All used scales of LCPI-v3 have high internal consistency - Cronbach's alpha vary from .70 to .95 [2].

\subsubsection{Procedure}

Data was collected on a voluntary basis via internet from January 2016 to May 2016.

\section{Results}

\subsection{Results of the research of relations between dimensions of anomia and maladaptive personality traits}

To clarify the relations between different dimensions of anomia (i.e., deviation from prescribed rules or customs, social distrust, estrangement to others, cultural isolation, lack of goal clarity and generalized sense of meaninglessness) and maladaptive personality traits (on facet and domain level) the Pearson's correlation analysis was used (Table 1).

\subsubsection{Correlations between measures of anomia and personality domains (first- order and second-order factors)}

As it was shown in the theoretical part of this paper, in the model of personality developed by Perepjolkina et al. [2] there are seven personality domains that form first-orders factors and four personality domains that form second-orders factors. At the first stage of data analysis associations between dimensions of anomia and these personality domains (firstorder and second-order factors) were analysed.

It was found that deviation from prescribed rules or customs as a dimension of anomia was not statistically significantly correlated with any of personality domains.

Social distrust was positively associated only with one first-order personality domain such as Negative emotionality $(p<.01)$, and none of the second-order factors of personality domains, including Neuroticism showed statistically significant correlations with this dimension of anomia.

Such dimension of anomia as estrangement to others was positively associated with (1) Psychoticism $(p<.01)$ and Introversion $(p<.01)$ that refer to such second-order factor as Schizotypy and correlation with this second-order factor was also significant $(p<.01)$; (2) Negative emotionality $(p<.01)$ and Dependence $(p<.01)$ that refer to such second-order factor as Neuroticism, and with Neuroticism itself $(p<.01)$; (3) Compulsivity $(p<.01)$.

Cultural isolation as a dimension of anomia was positively associated with such a firstorder factor as Psychoticism $(p<.01)$, and with corresponding second-order factor Schizotypy $(p<.01)$. 
Such dimension of anomia as lack of goal clarity was positively associated with (1) Psychoticism $(p<.05)$ and Introversion $(p<.05)$, and with corresponding to them secondorder factor Schizotypy $(p<.01)$; and with $(2)$ Negative emotionality $(p<.05)$ and Dependence $(p<.01)$ and with corresponding to them second-order factor Neuroticism $(p<.01)$.

Finally, such dimension of anomia as generalized sense of meaninglessness was positively associated with (1) Psychoticism $(p<.05)$ that refers to such second-order factor as Schizotypy; (2) Negative emotionality $(p<.01)$ and Dependence $(p<.01)$ that refer to such second-order factor as Neuroticism; (3) Compulsivity $(p<.05)$. Moreover, generalized sense of meaninglessness was positively associated with both Schizotypy $(p<.05)$ and Neuroticism $(p<.01)$.

Table 1. Pearson's correlations coefficients for measures of anomia and maladaptive personality traits.

\begin{tabular}{|c|c|c|c|c|c|c|}
\hline \multicolumn{7}{|c|}{ Correlations } \\
\hline \multirow{2}{*}{$\begin{array}{l}\text { Facet- and domain-level scales of } \\
\text { maladaptive personality traits }\end{array}$} & \multicolumn{6}{|c|}{ Dimensions of anomia } \\
\hline & $\begin{array}{c}\text { Deviation from } \\
\text { prescribed rules } \\
\text { or customs }\end{array}$ & Social distrust & $\begin{array}{c}\text { Estrangement to } \\
\text { others }\end{array}$ & Cultural isolation & $\begin{array}{l}\text { Lack of goal } \\
\text { clarity }\end{array}$ & $\begin{array}{c}\text { Generalized } \\
\text { sense of } \\
\text { meaninglessness }\end{array}$ \\
\hline Schizotypy & .023 & -.051 & $.610^{* *}$ & $.311^{* *}$ & $.275^{*}$ & $.254^{*}$ \\
\hline Psychoticism & .059 & -.035 & $.551^{* *}$ & $.330^{* *}$ & $.228^{*}$ & $.230^{*}$ \\
\hline Cognitive dysregulation & .074 & -.018 & $.286^{* *}$ & .214 & .080 & .086 \\
\hline Dissociation proneness & .129 & -.028 & $.419^{* *}$ & .162 & $.395^{* *}$ & .168 \\
\hline Eccentricity & -.002 & -.142 & $.420^{* *}$ & $.396^{* *}$ & .183 & .176 \\
\hline Suspiciousness & -.029 & .037 & $.577^{* *}$ & $.233^{*}$ & $.237^{*}$ & $.274^{*}$ \\
\hline Unusual beliefs & .047 & .068 & .176 & .092 & -.161 & .075 \\
\hline Self-harm & .008 & .052 & $.261^{*}$ & .117 & .105 & .133 \\
\hline Introversion & .018 & -.152 & $.473^{* *}$ & .195 & $.246^{\circ}$ & .135 \\
\hline Restricted affectivity & .139 & -.198 & $.379^{* *}$ & .127 & .211 & .146 \\
\hline Social withdrawal & -.101 & -.169 & $.375^{* *}$ & $.230^{*}$ & $.228^{\circ}$ & .087 \\
\hline Close relationship avoidance & .033 & .013 & $.313^{* *}$ & .073 & .117 & .082 \\
\hline Antagonism & .128 & .163 & .175 & -.087 & .069 & .057 \\
\hline Impusivity & .185 & .166 & .169 & .080 & .144 & .064 \\
\hline Aggression & -.015 & $.216^{*}$ & $.284^{* *}$ & -.024 & .063 & .136 \\
\hline Irresponsibility & $.254^{*}$ & .128 & .190 & .161 & .190 & .105 \\
\hline Rashness & .078 & .159 & .038 & -.002 & .173 & .095 \\
\hline Risk taking & .174 & -.015 & .032 & .088 & -.033 & -.122 \\
\hline Narcissism & .094 & .197 & .111 & -.192 & .026 & .043 \\
\hline Dominance & .013 & .198 & -.058 & -.210 & -.102 & .039 \\
\hline Arrogance & .190 & .025 & .134 & -.057 & .051 & .066 \\
\hline Attention seeking & .028 & .078 & .176 & -.198 & .096 & .035 \\
\hline Manipulativeness & -.027 & .206 & .132 & -.162 & .040 & .091 \\
\hline Harshness & .188 & .177 & .057 & -.019 & .050 & -.089 \\
\hline Deceitfulness & .082 & -.011 & $.258^{*}$ & .112 & .112 & .140 \\
\hline Neuroticism & -.057 & .179 & $.394^{* *}$ & .103 & $.405^{* *}$ & $.323^{* *}$ \\
\hline Negative emotionality & .012 & $.298^{* *}$ & $.333^{* *}$ & .101 & $.252^{*}$ & $.301^{* *}$ \\
\hline Intemperance & .014 & $.296^{* *}$ & .154 & -.018 & .089 & .131 \\
\hline Emotional stability & -.067 & $-.264^{*}$ & -.035 & -.001 & -.113 & -.072 \\
\hline Emotional lability & .029 & $.355^{* *}$ & $.243^{*}$ & .141 & .153 & $.245^{*}$ \\
\hline Depressivity & .000 & .118 & $.546^{* *}$ & .112 & $.426^{* *}$ & $.538^{* *}$ \\
\hline Anxiousness & -.059 & .081 & $.389^{* *}$ & .148 & $.275^{*}$ & $.270^{*}$ \\
\hline Impersistence & .006 & .057 & $.281^{*}$ & .146 & $.391^{* *}$ & .186 \\
\hline Distrustfulness & -.085 & .135 & $.391^{* *}$ & .152 & .170 & $.269^{*}$ \\
\hline Dependence & -.142 & .009 & $.367^{* *}$ & .055 & $.456^{* *}$ & $.281^{* *}$ \\
\hline Evaluation apprehension & -.156 & .075 & $.292^{* *}$ & -.060 & $.412^{* *}$ & $.247^{*}$ \\
\hline Submissiveness & -.096 & -.087 & $.331^{* *}$ & .178 & $.285^{* *}$ & $.228^{*}$ \\
\hline Indecisiveness & -.117 & -.032 & $.363^{* *}$ & .054 & $.423^{* *}$ & $.230^{*}$ \\
\hline Separation insecurity & -.092 & .046 & $.231^{*}$ & .047 & $.353^{* *}$ & $.221^{*}$ \\
\hline Compulsivity & -.062 & .067 & $.376^{* *}$ & .194 & .101 & $.226^{*}$ \\
\hline Pedantry & -.140 & .023 & $.332^{* *}$ & $.219^{*}$ & .030 & $.243^{*}$ \\
\hline Perseveration & .094 & .012 & .124 & -.024 & -.079 & .168 \\
\hline Perfectionism & -.078 & .104 & $.352^{* *}$ & .211 & $.238^{*}$ & .097 \\
\hline
\end{tabular}




\subsubsection{Correlations between measures of anomia and facet-level personality traits}

As it was shown in the theoretical part of this paper, in the model of personality developed by Perepjolkina and colleagues [2] there are 33 facet-level personality traits. At the second stage of data analysis associations between dimensions of anomia and these personality traits were analysed.

Firstly, it was found that such dimension of anomia as deviation from prescribed rules or customs was positively associated with irresponsibility $(p<.05)$ that refers to such domain of personality (first-order factor) as impulsivity.

Secondly, it was found that such dimension of anomia as social distrust was positively associated with such maladaptive personality traits as $(1)$ aggression $(p<.05)$ that refers to such domain of personality as impulsivity (first-order factor) and (2) with three facet-level traits from first-order factor Negative emotionality: intemperance $(p<.01)$, emotional instability $(p<.01)$, and negatively was associated with emotional stability $(p<.05)$.

Thirdly, it was found that such dimension of anomia as estrangement to others was positively associated with such maladaptive personality traits as (1) cognitive nonregulation $(p<.01)$, dissociation proneness $(p<.01)$, eccentricity $(p<.01)$, suspiciousness $(p<.01)$, self-harm $(p<.05)$ that all refer to such domain of personality (first-order factor) as Psychoticism; (2) restricted affectivity $(p<.01)$, social withdrawal $(p<.01)$ and close relationship avoidance $(p<.01)$ that refer to Introversion (first-order factor); (3) aggression $(p<.01)$ that refers to Impulsivity (first-order factor); (4) deceitfulness $(p<.05)$ that refer to Narcissism (first-order factor); (5) emotional instability $(p<.05)$, depressiveness $(p<.01)$, anxiousness $(p<.01)$, impersistence $(p<.05)$, and distrustfulness $(p<.01)$ that refer to Negative emotionality (first-order factor); (6) evaluation apprehension $(p<.01)$, submissiveness $(p<.01)$, indecisiveness $(p<.01)$, separation insecurity $(p<.05)$ that refer to Dependence (first-order factor), and (7) pedantry $(p<.01)$ and perfectionism $(p<.01)$ that refer to such domain of personality (first-order factor) as Compulsivity.

Such dimension of anomia as cultural isolation was positively associated with (1) eccentricity $(p<.01)$ and suspiciousness $(p<.05)$ that refer to Psychoticism (first-order factor); (2) social withdrawal $(p<.05)$ that refers to Introversion (first-order factor), and (3) pedantry $(p<.05)$ that refer to such domain of personality (first-order factor) as Compulsivity.

It was discovered that such dimension of anomia as lack of goal clarity was positively associated with (1) dissociation proneness $(p<.01)$, suspiciousness $(p<.05)$ that refer to such domain of personality (first-order factor) as Psychoticism; (2) social withdrawal $(p<.05)$ that refers to Introversion (first-order factor); (3) depression $(p<.01)$, anxiousness $(p<.05)$, impersistence $(p<.01)$ that refer to Negative emotionality (first-order factor); (4) evaluation apprehension $(p<.01)$, submissiveness $(p<.01)$, indecisiveness $(p<.01)$, separation insecurity $(p<.01)$ that refer to Dependence (first-order factor), and (5) perfectionism $(p<.05)$ that refers to such domain of personality (first-order factor) as Compulsivity.

Finally, it was found that such dimension of personality as generalized sense of meaninglessness was positively associated with $(1)$ suspiciousness $(p<.05)$ that refers to such domain of personality (first-order factor) as Psychoticism; (2) emotional instability $(p<.05)$, depressiveness $(p<.01)$, anxiousness $(p<.05)$, and distrustfulness $(p<.05)$ that refers to such domain of personality (first-order factor) as Negative emotionality; (3) evaluation apprehension $(p<.05)$, submissiveness $(p<.05)$, indecisiveness $(p<.05)$ and separation insecurity $(p<.05)$ that refer to Dependence (first-order factor), and (4) pedantry $(p<.05)$ that refers to such domain of personality (first-order factor) as Compulsivity. 


\subsection{Results of the research of prediction of levels of anomia from indicators of personality domains and personality traits}

In order to determine which personality domains best predict dimensions of anomia regression analysis was performed. Regression analysis was performed three times, namely, using as predictors (1) second-order personality domains, (2) first-order personality domains, and (3) facet-level personality traits. This strategy will allow evaluation which personality domains with different level of generality (domains that are first-order factors and that are second order factors) as well lower level personality traits predict dimensions of anomia best of all.

\subsubsection{Prediction of dimensions of anomia from indicators of personality domains (second-order factors)}

As some dimensions of anomia, namely, deviation from prescribed rules or customs and social distrust were not related to any of personality domains that are second-order factors, for these dimensions of anomia regression analysis was not performed. In those cases when significant correlations between certain dimensions of anomia and some personality domains were found hierarchical multiple regression using Enter method was employed. In those cases when there was a significant correlation between one certain dimension of anomia and the only personality domain, simple linear regression was employed. Hierarchical multiple regression was performed to determine what personality domain that were second-order factors best of all predict estrangement to others, lack of goal clarity, and generalized sense of meaninglessness. Simple regression was employed to find whether and to what extent personality domain predicts the indicators of cultural isolation. Table 2 summarizes the results of regression analysis on dimensions of anomia as dependent variable.

Table 2. Regression analysis summary for personality domains (second-order factors), predicting dimensions of anomia.

\begin{tabular}{lllc}
\hline & $\boldsymbol{\beta}$ & $\boldsymbol{R}^{\mathbf{2}}$ & $\boldsymbol{F}$ \\
\hline Estrangement to others & & & \\
\hline Step 1 & & .37 & $48.04^{* * *}$ \\
Schizotypy & $.61^{* * *}$ & & \\
\hline Step 2 & & .38 & $24.97^{* * *}$ \\
Schizotypy & $.55^{* * *}$ & & \\
Neuroticism & .13 & & $16.84^{* * *}$ \\
\hline Step 3 & & .39 & \\
Schizotypy & $.52^{* * *}$ & & \\
Neuroticism & .10 & & \\
Compulsivity & .09 & & \\
\hline Cultural isolation & & .10 & \\
\hline Schizotypy & $.31^{* * *}$ & & \\
\hline
\end{tabular}


Table 2 continuation. Regression analysis summary for personality domains (second-order factors), predicting dimensions of anomia.

\begin{tabular}{llll}
\hline Lack of goal clarity & & & \\
Step 1 & .16 & $15.86^{* * * *}$ \\
$\quad$ Neuroticism & & .17 & $8.28^{* *}$ \\
\hline Step 2 & $.36^{* *}$ & & \\
$\quad$ Neuroticism & .10 & & \\
Schizotypy & & & $9.43^{* *}$ \\
\hline Generalized sense of meaninglessness & & .10 & $5.27^{* *}$ \\
\hline Step 1 & $.32^{* *}$ & & \\
Neuroticism & & .12 & $3.58^{*}$ \\
\hline Step 2 & $.26^{*}$ & & \\
Neuroticism & .13 & & \\
Schizotypy & & .12 & \\
\hline Step 3 & .24 & & \\
Neuroticism & .11 & & \\
Schizotypy & .07 & & \\
Compulsivity & & & \\
\hline
\end{tabular}

Note: $* p<.05, * * p<.01, * * * p<.001$.

The regression analysis reveals that Schizotypy best of all predicts estrangement to others. Neuroticism in the second model does not significantly improve the prediction $\left(R^{2}\right.$ change $\left.=.002, F(1,80)=1.57, p>.05\right)$ as well as Compulsivity in the third model also does not improve the prediction $\left(R^{2}\right.$ change $\left.=.006, F(1,79)=.75, p>.05\right)$.

Schizotypy is the only significant predictor for cultural isolation.

It was found that Neuroticism best of all predicts lack of goal clarity. Schizotypy in the second model does not significantly improve the prediction $\left(R^{2}\right.$ change $=.008$, $F(1,80)=.76, p>.05)$.

The regression analysis reveals that Neuroticism best of all predicts generalized sense of meaninglessness. Schizotypy in the second model does not significantly improve the prediction $\left(R^{2}\right.$ change $\left.=.012, F(1,80)=1.10, p>.05\right)$. Compulsivity in the third model also does not improve the prediction $\left(R^{2}\right.$ change $\left.=.003, F(1,79)=.30, p>.05\right)$.

\subsubsection{Prediction of dimensions of anomia from indicators of personality domains (first-order factors)}

As such dimension of anomia as deviation from prescribed rules or customs was not related to any of personality domains that are first-order factors, for this dimension of anomia regression analysis was not performed. In those cases when significant correlations between certain dimensions of anomia and some personality domains were found hierarchical multiple regression using Enter method was employed. In those cases when there was a significant correlation between one certain dimension of anomia and the only personality domain, simple linear regression was employed. Hierarchical multiple regression was 
performed to determine what personality domain that were first-order factors best of all predict estrangement to others, lack of goal clarity, and generalized sense of meaninglessness. Simple regression was employed to find whether and to what extent personality domain predicts the indicators of social distrust and cultural isolation. Table 3 summarizes the results of regression analysis on dimensions of anomia as dependent variable.

Table 3. Regression analysis summary for personality domains (first-order factors), predicting dimensions of anomia.

\begin{tabular}{|c|c|c|c|}
\hline & $\beta$ & $R^{2}$ & $\boldsymbol{F}$ \\
\hline \multicolumn{4}{|l|}{ Social distrust } \\
\hline Negative emotionality & $.30 * *$ & .09 & $7.90 * *$ \\
\hline \multicolumn{4}{|l|}{ Estrangement to others } \\
\hline Step 1 & & .30 & $35.40 * * *$ \\
\hline Psychoticism & $.55 * * *$ & & \\
\hline Step 2 & & .34 & $21.00 * * *$ \\
\hline Psychoticism & $.42 * * *$ & & \\
\hline Introversion & $.24 *$ & & \\
\hline Step 3 & & .37 & $15.15^{* * *}$ \\
\hline Psychoticism & $.35 * *$ & & \\
\hline Introversion & $.23 *$ & & \\
\hline Compulsivity & .16 & & \\
\hline Step 4 & & .37 & $11.50 * * *$ \\
\hline Psychoticism & $.32 * *$ & & \\
\hline Introversion & $.24 * *$ & & \\
\hline Compulsivity & .13 & & \\
\hline Dependence & .09 & & \\
\hline Step 5 & & .37 & $9.18 * * *$ \\
\hline Psychoticism & $.30^{*}$ & & \\
\hline Introversion & $.24^{*}$ & & \\
\hline Compulsivity & .13 & & \\
\hline Dependence & .06 & & \\
\hline Negative emotionality & .07 & & \\
\hline Cultural isolation & & .11 & $9.93 * *$ \\
\hline Psychoticism & $.33 * *$ & & \\
\hline \multicolumn{4}{|l|}{ Lack of goal clarity } \\
\hline Step 1 & & .21 & $21.24 * * *$ \\
\hline Dependence & $.46 * * *$ & & \\
\hline
\end{tabular}


Table 3 continuation. Regression analysis summary for personality domains (first-order factors), predicting dimensions of anomia.

\begin{tabular}{|c|c|c|c|}
\hline Step 2 & & .21 & $10.54 * * *$ \\
\hline Dependence & $.48 * * *$ & & \\
\hline Negative emotionality & -.04 & & \\
\hline Step 3 & & .23 & $7.83 * * *$ \\
\hline Dependence & $.45^{* *}$ & & \\
\hline Negative emotionality & -.05 & & \\
\hline Introversion & .15 & & \\
\hline Step 4 & & .24 & $6.01 * * *$ \\
\hline Dependence & $.48 * *$ & & \\
\hline Negative emotionality & -.02 & & \\
\hline Introversion & .20 & & \\
\hline Psychoticism & -.11 & & \\
\hline \multicolumn{4}{|c|}{ Generalized sense of meaninglessness } \\
\hline Step 1 & & .09 & $8.07 * *$ \\
\hline Negative emotionality & $.30 * *$ & & \\
\hline Step 2 & & .11 & $4.77 *$ \\
\hline Negative emotionality & .21 & & \\
\hline Dependence & .16 & & \\
\hline Step 3 & & .11 & $3.30 *$ \\
\hline Negative emotionality & .19 & & \\
\hline Dependence & .13 & & \\
\hline Psychoticism & .08 & & \\
\hline Step 4 & & .12 & $2.57^{*}$ \\
\hline Negative emotionality & .18 & & \\
\hline Dependence & .11 & & \\
\hline Psychoticism & .06 & & \\
\hline Compulsivity & .08 & & \\
\hline
\end{tabular}

Note: ${ }^{*} p<.05,{ }^{* *} p<.01,{ }^{* * *} p<.001$.

The regression analysis reveals that Negative emotionality is the only significant predictor for social distrust.

It was found that Psychoticism best of all predicts estrangement to others. Introversion in the second model significantly improves the prediction $\left(R^{2}\right.$ change $=.040$, $F(1,80)=4.89, p<.05)$. Compulsivity in the third model does not significantly improve the prediction $\left(R^{2}\right.$ change $\left.=.021, F(1,79)=2.61, p>.05\right)$. Dependence in the fourth model also does not significantly improve the prediction $\left(R^{2}\right.$ change $=.006, F(1,78)=.70$, $p>.05)$. Also in the fifth model Negative emotionality does not significantly improve the prediction $\left(R^{2}\right.$ change $\left.=.003, F(1,77)=.33, p>.05\right)$. 
Psychoticism is the only significant predictor for cultural isolation.

The regression analysis reveals that Dependence best of all predicts lack of goal clarity. Negative emotionality in the second model does not significantly improve the prediction $\left(R^{2}\right.$ change $\left.=.001, F(1,80)=.078, p>.05\right)$. Introversion in the third model also significantly does not improve the prediction $\left(R^{2}\right.$ change $\left.=.021, F(1,79)=2.13, p>.05\right)$. Psychoticism in the fourth model also does not significantly improve the prediction $\left(R^{2}\right.$ change $\left.=.006, F(1,78)=.64, p>.05\right)$.

Finally, it was found that Negative emotionality best of all predicts generalized sense of meaninglessness. Dependence in the second model does not significantly improve the prediction $\left(R^{2}\right.$ change $\left.=.016, F(1,80)=1.42, p>.05\right)$. Psychoticism in the third model also does not significantly improve the prediction $\left(R^{2}\right.$ change $=.005, F(1,79)=.42$, $p>.05)$ as well as Compulsivity in the fourth model also does not significantly improve the prediction $\left(R^{2}\right.$ change $\left.=.005, F(1,78)=.45, p>.05\right)$.

\subsubsection{Prediction of dimensions of anomia from indicators of personality traits}

As some dimensions of anomia were not related to certain personality domains (secondorder and first-order), nevertheless these dimensions of anomia statistically significantly correlated with facet-level personality traits that referred to such personality domains. Therefore the additional question is which facet-level personality traits best of all predict dimensions of anomia. Taking into account a significant number of personality traits, namely, 33, in those cases when significant correlations between certain dimensions of anomia and some personality traits were found stepwise regression analysis was employed. The only exception is deviation from prescribed rules or customs as a dimension of anomia that correlated with the only facet-level personality trait - irresponsibility; in this case simple linear regression was employed. Table 4 summarizes the results of regression analysis on dimensions of anomia as dependent variable.

Table 4. Regression analysis summary for personality traits, predicting dimensions of anomia.

\begin{tabular}{llll}
\hline & $\boldsymbol{\beta}$ & $\boldsymbol{R}^{2}$ & $\boldsymbol{F}$ \\
\hline Deviation from prescribed rules or customs & & .06 & $5.58^{*}$ \\
\hline Irresponsibility & $.25^{*}$ & & \\
\hline Social distrust & & .13 & $11.70^{* *}$ \\
\hline Emotional lability & $.36^{* *}$ & & \\
\hline Estrangement to others & & & \\
\hline Model 1 & & $39.98^{* * *}$ \\
$\quad$ Suspiciousness & $.58^{* * *}$ & & \\
\hline Model 2 & & .39 & $25.73^{* * *}$ \\
$\quad$ Suspiciousness & $.39^{* *}$ & & \\
$\quad$ Depressivity & $.31^{* *}$ & & \\
\hline
\end{tabular}


Table 4 continuation. Regression analysis summary for personality traits, predicting dimensions of anomia.

\begin{tabular}{llll}
\hline Model 3 & & .43 & $19.40^{* * *}$ \\
Suspiciousness & $.31^{* *}$ & & \\
Depressiveness & $.31^{* *}$ & & \\
Distrustfulness & $.20^{*}$ & & $15.08^{* * *}$ \\
\hline Cultural isolation & & .16 & \\
\hline Eccentricity & $.40^{* * *}$ & & $17.91^{* * *}$ \\
\hline Lack of goal clarity & & & $13.54^{* * *}$ \\
\hline Model 1 & & .18 & \\
Depressiveness & $.43^{* * *}$ & & $33.05^{* * *}$ \\
\hline Model 2 & & .25 & \\
$\quad \begin{array}{ll}\text { Depressiveness } \\
\text { Separation insecurity }\end{array}$ & $.37^{* * *}$ & & \\
\hline Generalized sense of meaninglessness & & .29 & \\
\hline Depressiveness & $.54^{* * *}$ & & \\
\hline
\end{tabular}

Note: $* p<.05, * * p<.01, * * * p<.001$.

Firstly, it was found that irresponsibility is the only facet-level personality trait that predicts deviation from prescribed rules or customs explaining $6 \%$ of variance.

The regression analysis reveals that emotional instability best of all predicts social distrust explaining $13 \%$ of variance.

Using Stepwise method three models were found for predicting estrangement to others. It was found that suspiciousness best of all predicts estrangement to others. Depressiveness statistically significantly improves the prediction in the second model $\left(R^{2}\right.$ change $=.06$, $F(1,79)=7.98, p<.01)$ as well as distrustfulness statistically significant improves the prediction in the third model $\left(R^{2}\right.$ change $\left.=.03, F(1,78)=4.48, p<.05\right)$. Thus, the combination of three personality traits, namely, suspiciousness, depressiveness and distrustfulness best of all predicts estrangement to others explaining $43 \%$ of variance in total.

The regression analysis reveals that eccentricity best of all predicts cultural isolation explaining $16 \%$ of variance.

Using Stepwise method two models were found for predicting lack of goal clarity. It was found that depressiveness best of all predicts lack of goal clarity while separation insecurity statistically significantly improves the prediction in the second model $\left(R^{2}\right.$ change $\left.=.07, F(1,80)=7.69, p<.01\right)$. Thus, the combination of two personality traits, namely, depressiveness and separation insecurity best of all predicts lack of goal clarity explaining $25 \%$ of variance in total.

Finally, the regression analysis reveals that depressiveness best of all predicts generalized sense of meaninglessness explaining $29 \%$ of variance. 


\section{Discussion}

The present study was designed to investigate the relationship between anomia and pathological personality traits. In particular, two research questions were formulated: (1) What are the relations between dimensions of anomia and pathological personality domains and facet-level traits? (2) What pathological personality domains and traits best predict specific dimensions of anomia?

It was found that the first dimension of anomia - deviation from prescribed rules or customs - was positively associated with one personality trait - irresponsibility. However, associations between deviation from prescribed rules or customs and first- and second-order personality domains were not found. Irresponsibility is the only personality trait that predicts deviation from prescribed rules or customs. This finding is obvious, because a lack of readiness to be responsible for own behaviour, to respect and complete financial and other requirements, disrespect regarding own promises as an essence of such personality trait as irresponsibility will serve as a base for deviation from prescribed rules or customs for a person in an "anomic state".

It was found that the second dimension of anomia, namely, social distrust, was positively associated with such personality traits as aggression, intemperance, emotional instability, and was negatively associated with emotional stability. Social distrust was positively associated with a first-order personality domain Negative emotionality. However, social distrust was not associated with any of second-order personality domains. Emotional instability as a pathological personality trait best of all predicts social distrust. Respectively, it was found that Negative emotionality is the only significant predictor for social distrust. These obtained results allow to assume, that emotional imbalance, difficulties in emotional control, sharp changes in mood as personality characteristics primarily will allow to expect that in the anomic state a person will lose social trust, that he/she will feel a lack of trust to government and other social institutions as well as a lack of trust to other people, that is, will have doubts that others are generally fair, honest and respect presumed norms.

It was found that the third dimension of anomia - estrangement to others - was positively associated with such maladaptive personality traits as cognitive non-regulation, dissociation proneness, eccentricity, suspiciousness, self-harm, restricted affectivity, social withdrawal, close relationship avoidance, aggression, deceitfulness, emotional instability, depressiveness, anxiousness, impersistence, distrustfulness, evaluation apprehension, submissiveness, indecisiveness, separation insecurity, pedantry and perfectionism. Estrangement to others was positively associated with such first-order personality domains as Psychoticism, Introversion, Negative emotionality, Dependence and Compulsivity. Estrangement to others was positively associated also with second-order personality domains, namely, Schizotypy, Neuroticism, and Compulsivity. The combination of three facet-level personality traits, namely, suspiciousness, depressiveness and distrustfulness best of all predicts estrangement to others. Regarding first-order personality domains it was found that Psychoticism together with Introversion best of all predicts estrangement to others. Regarding second-order personality domains it was found that Schizotypy best of all predicts estrangement to others. These obtained results allow to assume that more likely suspiciousness that fall within a first-order domain Psychoticism and a second-order domain Schizotypy is the most significant predictor of estrangement to others as a dimension of anomia. Really, suspicious attitude towards others as a stable personality trait, tendency to have doubts regarding loyalty of the others should serve as a base for a sense of estrangement to others, that is, senses of a lack of social support, loneliness, alienation, inferiority when a person endures anomia.

It was found that the fourth dimension of anomia - cultural isolation - was positively associated with such maladaptive personality traits as eccentricity, suspiciousness, social 
withdrawal and social detachment, and pedantry. Cultural isolation was positively associated with a first-order domain Psychoticism and a second-order domain Schizotypy. Eccentricity as a pathological personality trait best of all predicts cultural isolation. Psychoticism as a first-order personality domain is the only significant predictor for cultural isolation and, respectively, Schizotypy is the only significant predictor for cultural isolation. Thus, exactly, eccentricity as unusual, strange behaviour, speech and beliefs will as stable personality characteristics will serve as a base for such an anomic sign as a sense of a loss of internalized social norms and values that is an indicator of cultural isolation in the anomic state.

It was found that the fifth dimension of anomia - lack of goal clarity - was positively associated with such pathological personality traits as dissociation proneness, suspiciousness, social withdrawal and social detachment, depressiveness, anxiousness, impersistence, evaluation apprehension, submissiveness, indecisiveness, separation insecurity, and perfectionism. Lack of goal clarity was positively associated with such firstorder domains as Psychoticism, Introversion, Negative emotionality and Dependence as well as with such second-order domains as Schizotypy and Neuroticism. The combination of two personality traits, namely, depressiveness and separation insecurity best of all predicts lack of goal clarity. Dependence as a first-order domain best of all predicts lack of goal clarity and, respectively, Neuroticism as a second-order domain best of all predicts lack of goal clarity. These obtained results allow us to assume that more likely separation insecurity that fall within a first-order domain Dependence and a second-order domain Neuroticism is the most significant predictor of a lack of goal clarity as a dimension of anomia. Really, fear to stay alone, doubts that significant others "will stay with me", fear that nobody will promote necessary support and care, a lack of belief that "I'm able to take care about myself" can force a person to feel doubts in the anomic state that he/she is able to attain important life goals. In order to conceptualize this state Bandura [33] used a term of self-efficacy that means the extent or strength of one's belief in one's own ability to complete tasks and reach goals. Likely, that if a person feels lonely and is unsure that anyone will support his/her plans, intentions, and dreams, feels fear to lose significant others, he/she can refuse some important life goals and as a result feels uncertainty regarding own future.

Finally, the last sixth dimension of anomia, namely, generalized sense of meaninglessness, was positively associated with such pathological personality traits as suspiciousness, emotional instability, depressiveness, anxiousness, distrustfulness, evaluation apprehension, submissiveness, indecisiveness, separation insecurity, and pedantry. Generalized sense of meaninglessness was positively associated with such firstorder domains as Psychoticism, Negative emotionality, Dependence, and Compulsivity. Generalized sense of meaninglessness was positively associated with such second-order domains as Schizotypy, Neuroticism, and Compulsivity. Depressiveness as a pathological personality trait best of all predict generalized sense of meaninglessness. Negative emotionality as a first-order domain best of all predicts generalized sense of meaninglessness and, respectively, Neuroticism as a second-order domain best of all predicts generalized sense of meaninglessness. Thus, exactly depressiveness can be viewed as the most important pathological personality trait in prediction of generalized sense of meaninglessness. If a person has a tendency to feel dejectedness, unhappiness, pessimism, hopelessness and these characteristics are typical for him/her, then in the anomic state more likely he/she will experience as a state of generalized meaninglessness.

Thus, this study contributes to the knowledge and understanding of such issue as personality factors predicting anomia.

Limitations and future directions. One of the main limitations of this research is the size of the sample. We can perceive this research only as a pilot study. Secondly, the 
majority of respondents were females. In spite of the fact that in the previous research [22] sex differences in levels of anomia have not been found, in future, regarding the relations between anomia and pathological personality traits it would be important to organize a sample in which females and males would be represented equally. In future it would be necessary to realize a similar study in a more representative sample.

The paper was supported by the National Research Program 5.2. "Economic Transformation, Smart Growth, Governance and Legal Framework for the State and Society for Sustainable Development - a New Approach to the Creation of a Sustainable Learning Community (EKOSOC-LV)" and by Latvian National Research Programme Biomedicine for Public Health (BIOMEDICINE) 2014-2017 (sub-project Nr.5.8.2.).

\section{References}

1. J. L,evina, K. Mārtinsone. Psychometric properties of the anomia questionnaire (AQ) (in press)

2. V. Perepjolkina, J. Koḷesņikova, K. Mārtinsone, A. Stepens. Latvijas Klīniskais personības tests (LKPT-v3). Tehniskā rokasgrāma (in press)

3. É. Durkheim. The Division of Labour in Society. NY: Free Press ([1893] 1964)

4. R.K. Merton. Anomie, Anomia, and Social Interaction: Contexts of Deviant Behavior. In M.B. Clinard (Ed.) Anomie and Deviant Behavior: A Discussion and Critique (pp. 213-242). NY: Free Press (1964)

5. E. Lytkina. From anomie to alienation: An approach towards the measurement of social well-being and deviance. Papers of the IV Russian Sociology Congress. Moscow: Institute of Sociology RAN, Russian Sociological Society, 8227-8231 (2012)

6. J. Levina, K. Martinsone, \& D. Kamerade. Anomia as a factor predicting subjective well-being. Med. psihol. Ross, 3(32), iegūts no: http: / /www . mprj . ru/ archiv_global/2015_3_32/nomer07.php (2015)

7. J. L.evina, K. Mārtinsone. Anomia, social participation and subjective well-being: A psychological perspective. SOCIETY. INTEGRATION. EDUCATION. Proceedings of the International Scientific Conference (in press)

8. J. Levina, K. Mārtinsone, \& K. Klince. Relations between anomia and values of the inhabitants of the Baltic states. SOCIETY. INTEGRATION. EDUCATION. Proceedings of the International Scientific Conference, Vol. 1 (pp. 431-446). Rēzekne: RA izdevniecība. doi:10.17770/sie2016vol1.1518 (2016)

9. J. Ĺevina, K. Mārtinsone, \& D. Kamerāde. The relationship between anomia and participation of Latvian inhabitants in social activities. International Interdisciplinary Scientific Conference "Society. Health. Welfare." Proceedings (2016)

10. A.F. De Man, C.P. Leduc. Suicidal ideation in high school students: Depression and other correlates. Journal of Clinical Psychology 51(2), 173-181 (1995)

11. A. Heydari, A. Teymoori, \& H. Nasiri. Development of suicidality within socioeconomic context: Mediation effect of parental control and anomie. Omega 68(1), pp. 63-76 (2013-2014)

12. D.I. Lasky, J.T. Ziegenfuss (1979). Anomie and drug use in high school students. The International Journal of the Addiction 14(6), 861-866 (1979)

13. A.F. De Man, L. Labrèche-Gauthier, \& C.P. Leduc. Correlates of anomie in FrenchCanadian adolescents. The Journal of Social Psychology 133(2), 141-145 (1993) 
14. C.C. Conway, M.G. Craske, R.E. Zinbarg, S. Mineka. Pathological personality traits and the naturalistic course of internalizing disorders among high-risk young adults. Depression and Anxiety 33(1), 84-93 (2016)

15. T.F. Williams, K.M. Thomas, M.B. Donnellan, C.J. Hopwood. The aversive interpersonal behaviours associated with pathological personality traits. Journal of Personality Disorders 28(6), 824-840 (2014)

16. E.A. Dowgwillo, K.S. Ménard, R.F. Krueger, A.L. Pincus. DSM-5 Pathological Personality Traits and Intimate Partner Violence Among Male and Female College Students. Violence and Victims 31(3), 416-437 (2016)

17. I. Ramos-Grille, M. Gomà-i-Freixanet, N. Aragay, S. Valero, V. Vallès. Predicting treatment failure in pathological gambling: the role of personality traits. Addictive Behaviors 43, 54-59 (2015)

18. V. Zeigler-Hill, G.A. McCabe, J.K. Vrabel. The Dark side of humor: DSM-5 pathological personality traits and humour styles. Europe's Journal of Psychology 12(3), 363-376, doi: 10.5964/ejop.v12i3.1109

19. J. Levina, K. Martinsone, J. Kolesnikova, \& V. Perepjolkina. Possibilities of research of anomie in Latvian society. In A. Vētra, A.Vilks (Eds.) 5th International Interdisciplinary Scientific Conference "Society. Health. Welfare". 2nd Conference of Speech Therapists (Rīga, November 26-28, 2014): Abstracts (p. 39). Rīga: RSU (2014)

20. J. Levina, K. Martinsone. A revised integrative hierarchical model of anomia: Towards the construction of anomia indices. The 14th European Congress of Psychology "Linking technology and psychology: feeding the mind, energy for life" (Milan, Italy, 7-10 July 2015): Abstract book (p. 2250). Downloaded from http://www . ecp2015. it/wp-content/uploads/2015/07/ECP2015-Abstract-Book_upd27jul1.pdf (Accessed 31 July 2015) (2015)

21. J. Luevina, K. Mārtinsone, \& D. Kamerāde. Individuālās anomijas modeḷi Latvijas populācijāa. Rìgas Stradiña universitāte. 2015.gada zinātniskā konference: Tēzes (375.1 pp.). Rīga: RSU (2015)

22. J. L Levina, K. Mārtinsone, \& D. Kamerāde. Sex and Age Differences in Levels of Anomia of Latvian Inhabitants. SOCIETY. INTEGRATION. EDUCATION. Proceedings of the International Scientific Conference, Vol. 3 (pp. 567-576). Rēzekne: RA izdevniecība. doi: 10.17770/sie2015vol3.475 (2015)

23. J. L Levina, K. Mārtinsone, \& D. Kamerāde. A Model of Anomia in the Baltic States. The International Journal of Interdisciplinary Civic and Political Studies, 11(3), 1-12. doi: 10.18848/2327-0047/CGP (2016)

24. É. Durkheim. Suicide: A Study in Sociology. London, England: Routledge ([1897] 1951)

25. R.M. Maclver. The Ramparts We Guard. New York: The Macmillan Company (1950)

26. D.B. Samuel, D.R. Lynam, T.A. Widiger, \& S.A. Ball. An expert consensus approach to relating the proposed DSM-5 types and traits. Department of Psychological Sciences Faculty Publications. Paper 13. http: / / dx. doi .org/ $10.1037 / \mathrm{a} 0023787$ (2012)

27. T.A. Widiger, E. Simonsen. Alternative dimensional models of personality disorder: Finding a common ground. Journal of Personality Disorders 19(2), 110-130 (2005)

28. A.G.C. Wright, K.M. Thomas, C.J. Hopwood, K.E. Markon, A.L. Pincus, \& R.F. Krueger. The hierarchical structure of DSM-5 pathological personality traits. Journal of Abnormal Psychology 121(4), 951-995 (2012)

29. American Psychiatric Association. Diagnostic and Statistical Manual of Mental Disorders: DSM-5 (5 ${ }^{\text {th }}$ ed.). Arlington VA: American Psychiatric Association (2013) 
30. J. Kolesnikova, V. Perepjolkina, K. Martinsone, A. Stepens. The theoretical integrative model for the Latvian Clinical Personality Inventory. Society, integration, education. Proceedings of the International Scientifical Conference, Volume I. Rēzekne: RA izdevniecība, pp. 388-398. http: / / dx . doi .org/ 10.17770/sie2016vol1.1518 (2016)

31. V. Perepjolkina, J. Kolesnikova, K. Martinsone, A. Stepens, E. Rancans. Development of the pathological personality trait scales for the Latvian Clinical Personality Inventory (LCPI v2.2). Report presented at the 10th Conference of the ITC, Vancouver, Canada, July 1-4, 2016 (2016)

32. V. Perepjolkina, J. Kolesnikova, K. Mārtinsone, \& A. Stepens. Latvijas Klīniskā personības testa otrās sākotnējo apgalvojumu kopas izstrāde: integratīvās pieejas pielietošana. (Development of the Second Preliminary Item Pool of the Latvian Clinical Personality Inventory: an Integrative Approach). Society, integration, education. Proceedings of the International Scientifical Conference (Sabiedrība, integrācija, izglìtība. Starptautiskās zinātniskās konferences materiāli), Volume I, May 27th-28th, pp. 469-483. Rēzeknes Tehnolog̣iju akadēmija, 2016. http://journals.ru.lv/index.php/sIE/article/view/1521/16 $73(2016)$

33. A. Bandura. Self-efficacy: Toward a unifying theory of behavioral change. Psychological Review 84, 191-215 (1977) 
